\title{
Role of Negative Mood on Turkish Stock Market: Suicides
}

\section{Negatif Ruh Halinin Türk Borsası Üzerinde Oynadığı Rol: İntihar Olayları}

\author{
Ibrahim BOZKURT, Çankırı Karatekin University, ibozkurt@karatekin.edu.tr
}

\begin{abstract}
Psychology literature founds that suicides are the happiness barometers of societies and negative mood of society has a dominant role in the increment of suicide cases. This study uses suicide cases as the proxy variable of mood and investigates its effect on Turkish stock market. Our study finds co-incidence in periods of increased suicide rates with hike in the stock returns in the Turkish stock exchange. This upshot is consistent with the hypothesis that negative mood increases the demand for risky assets. Furthermore, this study explains how specifically the Turkish market returns are affected by the negative mood of society from psychological point of view. One of the major contributing facts is, individuals in a negative mood demand for risky assets in order to reward themselves.
\end{abstract}

Keywords: Negative Mood, Suicide, Investment Decision, Stock, Bourse Istanbul.

Öz: Psikoloji literatürünün ortaya koyduğu kanttlara göre; intiharlar, toplumların mutluluk barometresidir ve intiharlarda artışın yaşandığ dönemlerde, toplumda negatif ruh hali hâkimdir. Bu çalıșma; intihar vakalarını, ruh halinin vekil değișkeni olarak kabul etmekte ve intiharların Türk Borsası üzerindeki etkisini incelemektedir. Çalışma sonuçlarına göre; intihar vakalarında artışın yaşandı̆̆ dönemlerde, Türkiye borsasındaki hisse getirileri artmaktadır. Bu sonuç, negatif ruh halinin riskli varlıklara olan talebi artıracağ hipotezi ile tutarlıdır. Çallşma sonucu, Türkiye piyasası özelinde, psikoloji literatüründe yer bulan şu düşünce ile açıklanabilir; negatif ruh haline sahip bireyler, kendilerini ödüllendirmek için riskli varliklara yönelirler.

Anahtar Sözcükler: Negatif Ruh Hali, Intihar, Yatırım Kararl, Hisse Senedi, Borsa İstanbul.

\section{Introduction}

The role of mood in the decision making under risk has constantly been analyzed in behavioral economic studies both in laboratory and field experiments. Laboratory experiments have shown that $\operatorname{mood}^{1}$ affects the individual's risk perception and by this way shapes his or her choice making. Bower (1981), Johnson and Tversky (1983), Isen et al. (1978), Schwarz and Clore (1983), Schwarz and Clore (1988) and Wright and Bower (1992) found that, the most determining element in decision making is the mood and the mood affects a lot of factors such as risk perception or risk tolerance that determine financial choices ${ }^{2}$. In laboratory experiments, to identify the relationship between mood and risk perception, the moods of the subjects were changed in the positive or negative direction, asking them to watch short videos, listen to music, read short stories and giving them small present (e.g. Johnson and Tversky, 1983; Bruyneel et al., 2009; Yuen and Lee, 2003). Whereas, in field experiments, individual's mood is represented with some factors like weather and full moon. For instance, factors like (i)weather (Saunders, 1983), (ii)full moon (Bozkurt, 2015), (iii)football competition results (Berument and Ceylan, 2012; Bozkurt, 2014), (iv)day light (Hirshleifer and Shumway, 2003), (v) TV series finales (Lepori, 2015), (vi)air pollution (Levy and Yagil, 2011), (vii)seasons (Cao and Wei, 2005) and (viii)religious festivals (Białkowski, Etebari and Wisniewski, 2012) are used as mood proxy variables to explain the exogenous variations in the risk perception and decision making of investors. In field experiments just as lab experiments, it is confirmed that mood has an effect on the individual's risk perception and his decisions under risk.

Different from the established literature on the role of negative mood, the basic aim of this paper is to analyze the effect of suicide rates on buying-selling decisions of the investors (stock prices) in Istanbul Stock Exchange (Bourse Istanbul, BIST). Psychological studies took suicides as the happiness barometers of societies and during periods of increases in suicides, a negative mood dominates over the society. Therefore in this study suicide rates are taken as a novel mood proxy to investigate the response of the Turkish stock market to variations in investor mood.

This study tests following two opponent theories that originated from the laboratory: (i) Negative mood increases the risk perception and decreases the demand for risky assets; (ii) negative mood decreases the risk perception and increases the demand for risky assets. Most of the prior studies in psychology have reported plausible results showing that negative (positive) mood increases (decreases) the investor's risk perception and reduces (enhances) demand for risky assets (Schwarz and Clore, 1983; 1988; Yuen and Lee, 2003; Myer et al., 1992). However, relatively few studies in psychology reject this positive relationship between mood and tendency to take risk (e.g., Isen and Patrick, 1983; Leith and Baumeister, 1996; Bruyneel et al., 2009) and report opposite relationships between these factors. According to this notion, the positive mood avoids risk as a potential loss will ruin the positive mood of the stakeholder (Hockey et

\footnotetext{
${ }^{1}$ Psychologists as their discipline requires, differentiate concepts of "affect", "mood" and "emotion" from one another but in behavioural finance they are used instead of one another (Lepori, 2010). In this paper, they will be used as in behavioural finance.

${ }^{2}$ Because of this, supposing that "investors are rational at the decision making" is a basic but irrational assumption of economic and financial theories (e.g. efficient market hypothesis and modern portfolio theory). It is known that in real life, investors often digress from the aim of maximizing their profit and present irrational behaviours (Stracca, 2004).
} 
al., 2000). The negative mood, on the other hand, takes higher risks in order to gain more to repair their negative feelings (Mittal \& Ross, 1998).

The following sections of the study are designed to depict some studies in the literature related to suicide-mood and mood-investing in risky assets, the explanations related to the data and methodology of the study, the empirical results and the conclusion of the study.

\section{Suicide, Mood And Decision To Invest In Risky Assets}

\subsection{The Relationship between Suicides and Mood}

Suicides have increased year by year in many countries and today suicide is accepted as a universal issue (Batıün, 2008). In general, a lot of economical, sociological and psychological factors are reasons that cause individuals to commit suicide. It is observed that in periods of economic recession, bankrupt firms and financial crisis, suicide tendencies and suicides rise (Kütük, 2011; Triantafyllou and Angeletopoulou, 2011; Reeves et al., 2012). Depression, drug addiction, some psychological disorders, family problems, lack of social support and migration cause a rise in suicides (Özgüven et al., 2003; Large et al., 2011; Eskin, Kaynak and Demir, 2005). Furthermore, some more natural and men made reasons are pointed as cause of suicides, such as; (i) seasons (Makris et al., 2013), (ii) full moon ${ }^{3}$, (iii) weather (Salib, 1997), (iv) suicide broadcasts (Chen, Chen and Yip, 2011), (v) air pollution (Bakian et al., 2015) and (vi) sports activities (Encrenaz et al., 2012) are also the factors thought to effect suicide behaviours in a positive or negative way ${ }^{4}$.

The majority of people who commit suicide have a negative mood (Kaplan and Sadock, 2004), therefore the decrease or increase in suicides are accepted as a society's happiness barometers (Atasoy and Ertürk, 2014). Thus the rises in suicides are interpreted as the indicators of a negative mood and vice versa. In this article, the periods of rises in suicide rates are accepted as times of negative mood domination over the society and the way those times affect individual's investments in risky assets is analyzed.

\subsection{Effect of Mood on Demand for Risky Assets}

The decision maker is under the influence of his mood at each level of decision making (Loewenstein et al., 2001). As stated in the studies of Bower (1981), Johnson and Tversky (1983), Isen et al. (1978), Kavanagh and Bower (1985) and Wright and Bower (1992), the mood of the individual shapes his final judgment at the decision making process in the same direction. This means that the individual who is in a negative mood will be more pessimistic in his decisions compared to an individual who is in a positive mood. This situation can be explained with the effect of "mood congruency" or "mood dependency". Mood dependency is to remember certain experiences at a certain mood and repeat them each time of getting in that mood (Barry, Naus and Rehm, 2006). According to the mood dependency effect, investors will avoid the stock investment (risk) whenever they are in a negative mood if they were negatively affected by that investment made in negative mood (also the reverse of the situation is possible). Mood congruency refers to a match in valence between a person's mood and his or her thoughts (Myer et al., 1992). In the mood congruency effect, the individual's thought fits own mood. This means if the investor is in a negative (bad) mood he or she continuously thinks of bad thoughts or fears (e.g. fears of losing money). Thus he avoids risk, his risk perception increases and his desire to tolerate risk decreases. An exact opposite situation is valid for positive mood. Thaler and Johnson (1990) emphasize that the tendency to take risks will increase when the individual has prior gains (i.e. individual is in a positive mood). "Affect as information theory" can explain the relationship between the individual's mood and his decisions (his risk perception). This theory suggests that before making a decision, individuals make an evaluation asking themselves "What do I feel about this?" or "How do I feel?" about the situation they encountered and the result of this evaluation is highly effected by their mood (Schwarz and Clore, 1983; 1988). Therefore an individual who is in a negative mood will be more pessimistic in his decision compared to an individual who is in a positive mood. For instance Yuen and Lee (2003) experienced that when they induced depressed mood in the subjects by making them watch some videos, their risk-taking tendencies diminished.

The final result obtained from this first group of views is; when a negative mood dominates a period, individuals' risk perception will raise and they will avoid the risk. Avoiding risk will reduce the demand for risky assets and the prices of these assets (here, stocks).

The majority of researches support strongly that positive (negative) mood increases (decreases) the tendency to take risks (Yuen and Lee, 2003). On the contrary, few studies reported that partially or totally reject the positive relationship between mood and the willingness to take risks and show the relationship is completely opposite. Isen and Patrick

\footnotetext{
${ }^{3}$ Although no statistical relationship has been found by the lots of empirical studies done, majority of medical specialists and emergency staff think that full moon increases suicide and crime events (Vance, 1995).

${ }^{4}$ It must be taken into consideration that, the factors which have been demonstrated empirically to affect suicide behaviours have been used as mood proxy variables in a lot of studies in behavioural finance literature. This detection is a proof that suicide cases can be used as a representative of mood.
} 
(1983) analyze the effect of positive mood on risk taking and observe that people in positive mood avoid risk more, compared to people in neutral mood. Arkes, Herren and Isen (1988), Isen and Geva (1987) and Nygren et al. (1996) state that people in positive mood tend to avoid risk when the loss probability is great. The reason behind avoiding risk in positive mood is a probable loss will destroy positive mood. However, the individual will retain his constant positive mood avoiding risk (Hockey et al., 2000). They claim that the relationship between positive mood and tendency to prefer risky choices is not always positive. Contrary to what mentioned before, the individuals in negative mood also do not always avoid risks. A study shows that sad participants tend to take higher risks (Raghunathan and Pham, 1999). Bruyneel et al. (2009) also point out that individual in a negative mood switches into risky assets. Thaler and Johnson (1990) reveal that people who experience prior losses (i.e. people who are in negative mood) find risky choices more attractive for the purpose of recovering the losses (break-even effects). Leith and Baumeister (1996) specify that people in negative mood prefer risky choices more, compared to riskless choices. Lin, Yen and Chuang (2007) give evidences that people feeling sad at the moment of decision making want to take risks more and prefer choices likely to gain. Conte, Levati and Nardi (2013) point out that sadness, anger and fear instigate risk-seeking behavior. The reason why people in negative mood tend to take higher risk is; they have the hope to repair their negative feelings by the help of deriving higher gains (Mittal and Ross, 1998). Mick and Demoss (1990) and Zillmann (1988) explains this effect of negative mood with buying risky asset by mood changing factor of self-indulging or self-rewarding. Depressed people in negative mood buy themselves presents because they want to compensate their negative experiences with rewards. The mentioned arguments show that people in positive mood behave with the instinct of "mood maintenance" and people in negative mood behave with the "mood repair" instinct to repair mood (Isen and Geva, 1987).

The result obtained from the second group of views is that, in a negative mood dominated period when individuals have lower risk perception and higher risk tolerance, they will try to increase their gains taking high risks with the purpose of repairing mood. This will enhance the demand for risky assets and the prices of these assets (here, stocks).

\subsection{Literature Review}

There are a number of studies in the behavioral finance literature which are based on the abovementioned views of psychology. These studies aim to analyze the effect of mood on the investor's risk perception and his decision of investment in stock, which is a risky asset. In all of these studies, good or bad mood is represented with mood changing factors. Saunders (1993) mentions that investor's mood influences the investment decisions (implicitly the stock prices) and the weather affects his mood, too. Therefore he analyzes the relationship between the New York weather and NYSE returns. Bozkurt (2015) pointed out the negative effect of the full moon on the human psychology and used it as a proxy for negative mood. The findings show that during the full moon, demands for stocks and naturally their prices reduce. Berument and Ceylan (2012) express that results of football matches modify individuals' mood and they use football match results as a mood proxy variable. The defeats in football matches (negative mood) raise the investor's risk perception, lower the demand for stocks and reduce the stock prices. Hirshleifer and Shumway (2003) discuss that sunny weather is the reason for optimistic mood. Their study assumes sunny days as the mood proxy variable and found a statistically significant positive correlation between daylight and stock prices. Lepori (2015) specifies that the negative mood will dominate the society when the finale of TV series is watched. He employs the TV series finales as the representative of the negative mood. Findings show that stock prices response negatively to negative mood that occur in the society because of the finales of TV series (parasocial separations). Levy and Yagil (2011) predicate that air pollution negatively affects mood and use air pollution as proxy variable for negative mood. They reported a negative relationship between air pollution and stock returns which mean negative mood plunges down the demand for stocks. Cao and Wei (2005) found a negative relation between hot weather affected mood and human behavior on stock returns as summer months lazy mood in stock market is reported. Białkowski, Etebari and Wisniewski (2012) show that in Ramadan, Muslims have a positive mood and they use Ramadan as the positive mood proxy. They argue that during Ramadan, the stock returns are higher in a statistically significant way.

These studies and the likes in literature have two basic common characteristics. Firstly, in all of the related studies, the factors that are thought to affect mood are used as mood proxy variables. Secondly, almost all of the studies reported the negative (positive) mood affects the investment decisions and eventually the stock prices in a negative (positive) way.

This study employs, the suicide events caused by negative $\operatorname{mood}^{5}$ as negative mood proxy. Parallel to the studies in the psychology the study has got two hypotheses:

$\mathbf{H}_{1}$ : In periods of increase in suicide cases, in other words in periods of negative mood domination on society, the net demand for risky assets (stocks) decreases, thus the stock prices (returns) drop.

H1b: In periods of increase in suicide cases, in other words in periods of negative mood domination on society, the net demand for stocks increases, thus the stock prices (returns) increase, too.

There are two major contributions of this paper. First, for the first time in the literature, this study considers the numbers of suicide as a mood proxy to identify the effect of exogenous variations in investors' moods on their demands

\footnotetext{
${ }^{5}$ In the some studies (Henriksson et al., 1993; Kaplan \& Sadock, 2004) it was found that depressive mood or psychological disorders cause suicides and they increase suicide cases three or four times more than other psychiatric illnesses.
} 
for risky assets (stocks). Second, this study has robust findings that are coherent with few studies in psychology, but incoherent with studies in behavioral finance involving alternative mood proxies.

\section{Data}

The monthly suicide numbers were taken from Turkish Statistics Institute's (TSI) website ${ }^{6}$. In the 14 years between 2000 and 2013, the mean suicide rate is 228 per month. During that period, June 2012 was the term with the most suicide cases (325 people) and November 2000 was the term with the least (105 people). According to suicide data, in the related period in Turkey, nearly $50 \%$ of the individuals hanged themselves and nearly $25 \%$ used guns.

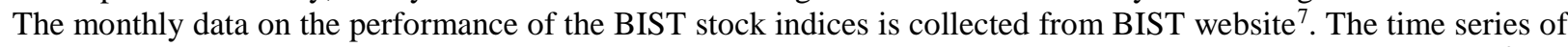
monthly closing values for the BIST-National-100, the BIST-Second-National and the BIST-All-Shares Indices ${ }^{8}$ are compiled. More than one index prices are used in order to determine the robustness of the results belonging to the relationship between suicide cases and stock prices. National-100 index which is used as the basic index for the Turkish stock market consists of 100 firms whose market values are the highest and it represents the National Market. SecondNational index consists of the stocks of firms trading on the Second National Market ${ }^{9}$. All-Shares index consists of all the stocks of the firms trading on the Turkish stock market, apart from "securities investment associations" and it represents both the National and the Second National Market. Table 1 shows the brief statistical information related to the mentioned indexes along with suicide rate during that period. Table 1 also shows the summary statistics for control variables. Macroeconomic control variables ${ }^{10}$ in Table 1 (Panel C) are used to control the probable effects of economic indicators on stock prices while determining the relationship between suicide cases and stock prices.

T-bill is an investment instrument which is an alternative to stocks. Therefore, T-bill interest rates affect stock demands and prices (Kuwornu and Owusu-Nantwi, 2011). A rise in T-bill rates diminishes the demand for stocks and the stock prices. Likewise, IP index is thought to have an effect on stock prices (Herve, Chanmalai and Shen, 2011). A rise in the IP index is expected to increase the stock prices. However, an increase in the IP may cause a decrease in stock prices if it is below the expected. Bankruptcy, which is the worst result of financial problems, affects badly both the bankrupt firm and all parties concerned such as debts, customers, workers, state and the family members. Studies point out that stock prices react to bankruptcy risk (Campbell et al., 2008; Dichev, 1998; Griffin and Lemmon, 2002). In this study, instead of bankruptcy risk, the numbers of bankrupt companies are used as data. These numbers can also represent the unemployment data ${ }^{11}$. Unemployment, which has negative effects on national economy, lowers the personal and national incomes. In a market of increasing unemployment stock prices are expected to decrease. It is also thought that gold and petrol prices and inflation rates have an effect on stock prices.

To find out the relationship between suicides and stock returns, data for eleven months of the year (except December) and Ramadan are used as dummy variables, controlling the most-known calendar anomalies (Chang and Pinegar, 1989; Lepori, 2015; Seyyed, Abraham and Al-Hajji, 2005). Finally, to control the other mood proxy variables, some weather parameters are employed such as; temperature values (Cao and Wei, 2005), cloud amounts (Saunder, 1993), amounts of precipitation (Dowling and Lucey, 2005) and wind speed values (Keef and Roush, 2005$)^{12}$.

Before stating the empirical analyses and to give some idea about the relationship between the index returns and suicides, the performance of National-100 index and the suicides in Turkey are given together in Figure (1).

\footnotetext{
${ }^{6}$ See, http://tuikapp.tuik.gov.tr/medas/?kn=115\&locale=tr. I obtained the data in 22.04.2015.

${ }^{7} \mathrm{See}$, http://www.borsaistanbul.com/en/data/data/index-data. I collected the indexes data in 25.04.2015. The stock exchange index gives information on the price movements of stocks in that index and has frequently been used in economic analyses to determine stock performances. An increase (decrease) in index shows that the investors in the market have decided to buy (sell) stocks.

${ }^{8} \mathrm{Check}$ http://www.borsaistanbul.com/docs/default-source/endeksler/bist-pay-endeksleri-temel-kurallari.pdf?sfvrsn=6, for detailed information on the related indices (25.04.2015).

${ }^{9}$ Second National Market is the market where the stocks of small and medium sized firms, firms excluded from the National Market for short-term or permanently and firms which could not provide the valid quotation and trading circumstances are traded.

${ }_{10}$ The data of related variables were obtained from:

The T-Bill interest rates = Republic of Turkey Prime Ministry Undersecretariat of Treasury (http://www.hazine.gov.tr/tr-TR/Istatistik-SunumSayfasi?mid=59\&cid=12) in 23.04.2015; The industrial production index data = Turkish Statistical Institute (http://www.tuik.gov.tr/PreTablo.do?alt id=1024) in 23.04.2015; The numbers of bankrupt firms, inflation and unemployment rates =

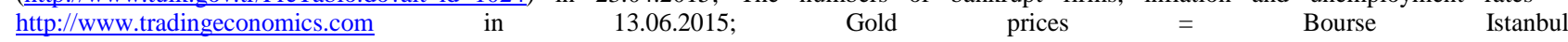
(http://www.borsaistanbul.com/dosyalar/kmtp/veriler/2014_aof_au.pdf) in 14.06.2015 and Oil prices = US Energy Information Administration (http://www.eia.gov/) in 14.06.2015.

${ }^{11}$ It is not possible to reach the monthly unemployment rates in Turkey before 2005 . The data used in the study belong to the $2005-2013$ period for this reason; unemployment rates will be included in the sub-period analysis in the "robustness check" section.

${ }^{12}$ The overall data related to the meteorological variables were obtained by e-mail in 25.05.2015 asked the Turkish State Meteorological Service with a letter of application dated 11.05.2015.
} 


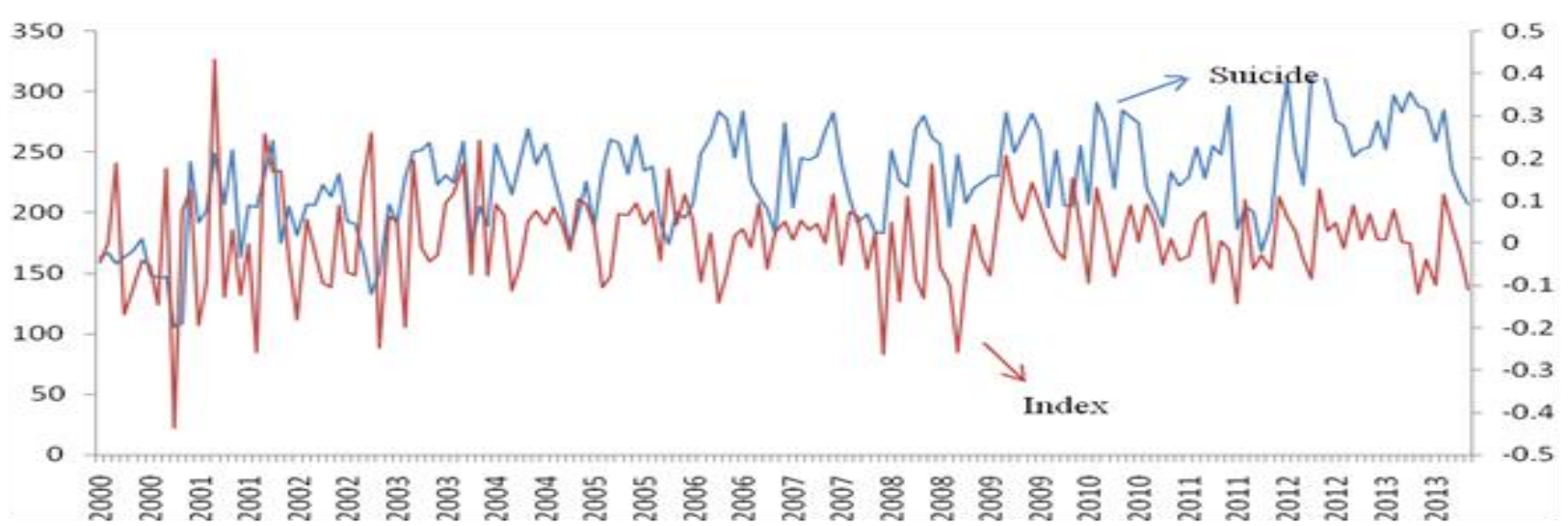

Fig. 1: Suicide Numbers and the Returns of BIST-National-100 Index.

Table 1: Summary Statistics of Stock Market Prices, Suicides and Control Variables

\begin{tabular}{|c|c|c|c|c|c|}
\hline Period: $2000-2013$ & Mean & St. Dev. & Median & Max & Min \\
\hline Monthly Suicide Numbers & 227.5 & 41.7 & 229.0 & 325.0 & 105.0 \\
\hline $\mathrm{A}^{\mathrm{a}}$ - BIST-National-100 & 37471.1 & 22150.7 & 37117.6 & 86046.0 & 7625.9 \\
\hline BIST-All-Shares & 36845.2 & 22171.0 & 36511.4 & 85043.9 & 7329.3 \\
\hline BİST-Second-National & 24245.0 & 7948.0 & 23239.2 & 58108.7 & 8528.6 \\
\hline $\mathrm{B}^{\mathrm{a}}-$ BIST-National-100 ${ }^{\mathrm{d}}$ & 0.0082 & 0.1115 & 0.0198 & 0.4328 & -0.4367 \\
\hline BIST-All-Shares ${ }^{\mathrm{d}}$ & 0.0086 & 0.1086 & 0.0202 & 0.4236 & -0.4349 \\
\hline BİST-Second-National ${ }^{\mathrm{d}}$ & 0.0019 & 0.1383 & 0.0129 & 0.5170 & -0.5889 \\
\hline$C^{a}-$ T-Bill Rates & 0.0183 & 0.0146 & 0.0136 & 0.0939 & 0.0041 \\
\hline IP Index ${ }^{b}$ & 86.7 & 18.8 & 90.6 & 120.4 & 52.9 \\
\hline Number of Bankrupt Firms & 781.4 & 518.4 & 689.0 & 3113.0 & 70.0 \\
\hline Inflation Rate (Change on CPI) & 0.25 & 0.82 & 0.10 & 10.55 & 0.04 \\
\hline Gold Prices (\$/Ons) & 792.5 & 487.6 & 641.8 & 1785.4 & 258.7 \\
\hline Brent Oil Prices (\$ per Barrel) & 64.7 & 33.4 & 62.1 & 132.7 & 18.7 \\
\hline Unemployment Rate ${ }^{\mathrm{e}}$ & 0.098 & 0.016 & 0.093 & 0.148 & 0.073 \\
\hline $\mathrm{D}^{\mathrm{a}}$ - Average Air Temperature in Istanbul $\left({ }^{\circ} \mathrm{C}\right)$ & 14.4 & 6.8 & 14.3 & 26.9 & 2.2 \\
\hline Average Cloudiness for Istanbul & 4.4 & 1.5 & 4.4 & 8.4 & 1.0 \\
\hline Total Precipitation in Istanbul (mm) & 2.4 & 2.0 & 2.0 & 10.9 & 0.0 \\
\hline Average Wind Speed in Istanbul (m/sec) & 2.7 & 1.0 & 2.3 & 6.0 & 1.0 \\
\hline $\mathrm{E}^{\mathrm{a}}-$ January $(\text { yes }=1 ; \text { no }=0)^{\mathrm{c}}$ & 0.0833 & 0.2772 & 0.0000 & 1.0000 & 0.0000 \\
\hline Ramadan $($ yes $=1 ;$ no $=0)$ & 0.1130 & 0.3176 & 0.0000 & 1.0000 & 0.0000 \\
\hline
\end{tabular}

Note: $\left.{ }^{a}\right)$ The entire data are monthly. Part A reflects index prices, Part B reflects index returns and Part $\mathrm{C}$ reflects the macroeconomic control variables, Part D reflects alternative mood proxies and Part E presents data concerning calendar variables. $\left({ }^{\mathbf{b}}\right)$ IP index data are rid of seasonal effects by the help of EViews program. $\left({ }^{c}\right)$ Not to make an extended table, the statistical informative data of the months except January are not given. $\left({ }^{\mathbf{d}}\right)$ The index returns (r), showing the increases (or decreases) in stock prices as a result of investors' stock buying (or selling) decision, are calculated using continuously compound return formula: " $\mathrm{r}_{t}=\ln \left(\mathrm{I}_{\mathrm{t}}\right)-\ln \left(\mathrm{I}_{\mathrm{t}-1}\right)$ )" where "It" represents the value of the index in month t. ( $\left.{ }^{\mathbf{e}}\right)$ The data concerning unemployment belong to the 2005-2013 period. (g) We employ the unit root test for time series and unit root problem was not observed in these variables. The results related to unit root tests are not reported here because of limited area.

\section{Empirical Analysis}

To determine the relationship between stock returns and suicides (negative mood) ordinary least squares (OLS) regression method is used. The most important problem in this method is that data may have outliers (Rousseeuw and Leroy, 1987). The OLS regression analyses carried out using outliers given deviant and inconsistent results. In this study the following procedures are implemented to eliminate the negative effects of outliers: (i) OLS regression 
analyses are performed without outliers ${ }^{13}$ and (ii) $\mathrm{M}$ estimator type (Huber, 1964) of Robust Least Squares (RLS) regression method is performed.

\subsection{Simple Model}

The model (1) below is utilized first in order to test the $\mathrm{H}_{1 \mathrm{a}}$ and $\mathrm{H}_{1 \mathrm{~b}}$ hypotheses of the study.

$$
r_{t}=\alpha+\beta_{1} \ln \left(\text { Suicide }_{t}\right)+\sum_{n=1}^{11} \gamma_{n} D M_{n t}+\delta_{l} D M R_{t}+\varepsilon_{t}
$$

In the model here, $r_{t}$ represents the realized return to each index in month $t$, Suicide $\mathrm{t}_{\mathrm{t}}$ represents the number of suicide cases in month $t$ in Turkey, $\mathrm{DM}_{\mathrm{nt}}$ is the dummy variable representing the eleven months in a year (except December) and $\mathrm{DMR}_{t}$ is dummy variable that takes a value of 1 if the month $t$ is Ramadan and the value of 0 otherwise.

The above regression model (1) covers the most well-known calendar anomalies (January and Ramadan) as dummy variables to control the effect of the related anomalies on the dependent variable and to ensure the robustness of the analysis results.

OLS regression analyses are performed using Newey-West method ${ }^{14}$. Table 2 shows the regression analysis results related to each of the stock market indexes.

Table 2: The Results of the Regression Analysis (Model 1).

\begin{tabular}{|c|c|c|c|c|c|c|}
\hline \multirow{2}{*}{$\begin{array}{l}\text { Dep. Var. } \\
\text { Method }\end{array}$} & \multicolumn{2}{|c|}{ National-100 } & \multicolumn{2}{|c|}{ All-Shares } & \multicolumn{2}{|c|}{ Second National } \\
\hline & OLS $\overline{\mathbf{d}}$ & ROBUST $^{\mathrm{e}}$ & $\mathbf{O L S}^{\mathbf{d}}$ & $\overline{\text { ROBUST }}^{\mathrm{e}}$ & $\mathbf{O L S} \overline{S^{d}}$ & $\overline{\text { ROBUST }}^{\mathrm{e}}$ \\
\hline \multirow[t]{2}{*}{ SUICIDE } & $0.14662^{\mathrm{a}}$ & $0.19425^{\mathrm{a}}$ & $0.14193^{\mathrm{a}}$ & $0.18735^{\mathrm{a}}$ & 0.06460 & 0.07927 \\
\hline & {$[0.016]$} & $(0.044)$ & {$[0.047]$} & $(0.043)$ & [0.069] & $(0.052)$ \\
\hline \multirow[t]{2}{*}{ MARCH $^{f}$} & $-0.06438^{c}$ & $-0.07802^{b}$ & $-0.05922^{c}$ & $-0.07379^{b}$ & -0.03368 & -0.03456 \\
\hline & {$[0.037]$} & $(0.038)$ & {$[0.035]$} & $(0.036)$ & [0.042] & $(0.044)$ \\
\hline \multirow[t]{2}{*}{ MAY } & $-0.11606^{a}$ & $-0.14107^{a}$ & $-0.11257^{a}$ & $-0.13935^{a}$ & -0.06599 & $-0.07826^{c}$ \\
\hline & {$[0.038]$} & $(0.038)$ & [0.037] & $(0.037)$ & [0.045] & $(0.045)$ \\
\hline \multirow[t]{2}{*}{ JUNE } & $-0.08782^{b}$ & $-0.11061^{a}$ & $-0.08482^{b}$ & $-0.10843^{a}$ & -0.04891 & -0.04035 \\
\hline & {$[0.038]$} & $(0.039)$ & {$[0.037]$} & $(0.037)$ & {$[0.050]$} & $(0.045)$ \\
\hline \multirow[t]{2}{*}{ AUGUST } & $-0.08630^{\mathbf{b}}$ & $-0.10246^{a}$ & $-0.08305^{b}$ & $-0.09956^{\mathbf{a}}$ & -0.03337 & -0.05815 \\
\hline & [0.034] & $(0.038)$ & [0.033] & $(0.036)$ & [0.056] & $(0.044)$ \\
\hline \multirow[t]{2}{*}{ RAMADAN } & 0.04118 & 0.02788 & 0.03926 & 0.02372 & -0.01375 & 0.00444 \\
\hline & {$[0.026]$} & $(0.026)$ & {$[0.025]$} & $(0.025)$ & [0.033] & $(0.030)$ \\
\hline \multirow[t]{2}{*}{$\alpha$} & $-0.74305^{a}$ & $-0.98285^{a}$ & $-0.71907^{a}$ & $-0.94540^{a}$ & -0.30268 & -0.37957 \\
\hline & {$[0.252]$} & $(0.235)$ & [0.242] & $(0.226)$ & [0.362] & $(0.274)$ \\
\hline Observations & 165 & 167 & 165 & 167 & 163 & 167 \\
\hline Adj. R-sq. & 0.08550 & 0.24676 & 0.08366 & 0.25359 & -0.04068 & 0.06561 \\
\hline F-statistic & $2.17952^{b}$ & & $2.15181^{b}$ & & 0.51283 & \\
\hline
\end{tabular}

Note: $\left({ }^{\mathbf{a}}\right),\left({ }^{\mathbf{b}}\right)$ and $\left({ }^{c}\right)$ have been used to indicate that the coefficient estimations are statistically significant at $1 \%, 5 \%$ and $10 \%$ level, respectively. $\left({ }^{d}\right)$ Since error terms may have heteroscedastic and autocorrelation problems, Newey-West method has been used in the analysis. The values given in brackets under related coefficient estimations are Newey-West robust standard errors made coherent with autocorrelation and heteroscedastic. $\left({ }^{\mathbf{e}}\right)$ Huber's M estimator is used in Robust Regression analyses. The values given in parenthesis under related coefficients are robust standard errors. $\left.{ }^{(}{ }^{f}\right)$ This table involves only the statistically significant test results related to calendar variables to narrow the research to a smaller area.

According to Table 2, coefficient $\beta_{1}$ is positive for two indexes (National-100 and All-Shares) and it is statistically significant at the $1 \%$ level. In other words, the null hypothesis that $\beta_{1}$ equal to 0 is rejected. However, the null hypothesis of $\beta_{1}=0$ is not rejected for the Second-National index. The positive sign of coefficient $\beta_{1}$ (for the two indexes) suggests that a rise in suicides in period $t$ increases the stock returns in the same period, other things being equal. A $20 \%$ jump in the suicides compared to the prior period is forecasted which leads to a $2.5 \%$ increase in the related indexes. According to robust regression results, this increase is estimated to be about 3.3\%. These findings for

\footnotetext{
${ }^{13}$ The outliers related to the indexes were determined manually by the help of Iglewicz and Hoaglin's (1993) modified Z score (M). The modified Z score $(M)$ is calculated as follows: $M_{i}=0.6745\left(x_{i}-\tilde{x}\right) / M A D$. In this equation $x_{i}$ is the value of period $i$; $\tilde{x}$ is the median of the series and $\operatorname{MAD}=\operatorname{median}\left\{\left|\mathrm{x}_{\mathrm{i}}-\tilde{\mathrm{x}}\right|\right\}$.

${ }^{14}$ Newey-West method gives robust standard errors in case there is a possibility that error terms in regression equations may have heteroskedastic and autocorrelation problems and provides coherent coefficient predictions.

${ }^{15}$ In fact, the intensity of the effect changes according to the suicide numbers of prior period. In this calculation, the number of the suicides in period (t-1) has been supposed to be equal to the average suicide cases (228) in 14 years in Turkey. According to this supposition, a 20\% increase in suicide numbers in month $t$ causes an increase in National-100 (or All-Shares) index returns in the same month, which is $E\left(r_{t}\right)-E\left(r_{t-1}\right)=\left[\beta_{1} \times \ln \left(\operatorname{Suicide} e_{t}\right)\right]-$ $\left[\beta_{1} \times \ln \left(\right.\right.$ Suicide $\left.\left._{\mathrm{t}-1}\right)\right]=[0.14 \times \ln (228 * 1.2)]-[0.14 \times \ln (228)]=0.025$.
} 
the model (1) is coherent with the hypothesis $\left(\mathrm{H}_{1 \mathrm{~b}}\right)$ that in periods when suicides increase and a negative mood dominates the society, the demand for stocks and their prices increases.

As for the rest of the variables; the coefficients of March, May, June and August dummies are statistically significant (different from zero) and negative for National-100 and All-Shares indexes. For instance, the average returns of the indexes in May are 11 basis points lower than that of the other months (nearly 14 basis points according to robust regression analysis).

Finally, when the independent variables are considered as a whole, the hypothesis that the coefficients of all independent variables are equal to zero cannot be rejected statistically only for the Second-National index $(\mathrm{f}=0.512)$.

The analysis results related to All-Shares (which represent both the national and second national market) and National-100 (which represents only the national market) indexes are fairly similar. This attests that stocks traded in National-100, the basic index for the Turkish stock market, steer the Turkish stock market.

\subsection{The Model Where Economic Indicators Are Controlled}

The regression model (1) does not contain macroeconomic variables. However, the changes in macroeconomic variables can affect stock prices (Ibrahim and Yusoff, 2001). In this context, the robustness of the analysis results must be verified by controlling the effect of economic variables on the dependent variable alongside calendar anomalies. In this way the model (1) is enlarged adding six macroeconomic variables to form the regression model (2) below. A good number of studies analyzed the effect of the added variables on the stock prices (Herve, Chanmalai and Shen, 2011; Kuwornu and Owusu-Nantwi, 2011; Narayan and Gupta, 2015; Al-Rjoub, 2005; Smith, 2001).

$$
\begin{aligned}
r_{t}= & \alpha+\beta_{1} \ln \left(\text { Suicide }_{t}\right)+\sum_{n=1}^{11} \gamma_{n} D M_{n t}+\delta_{1} D M R_{t}+\lambda_{l} r_{t-1} \\
& +\lambda_{2} \text { TBill }_{\mathrm{t}}+\lambda_{3} \text { IPindex }_{\mathrm{t}}+\lambda_{4} \text { Gold }_{\mathrm{t}}+\lambda_{5} \text { Oil }_{\mathrm{t}}+\lambda_{6} \text { Inflation }_{\mathrm{t}}+\lambda_{7} \text { Bankrupt }_{\mathrm{t}}+\varepsilon_{t}
\end{aligned}
$$

Where, Tbill $\mathrm{t}_{\mathrm{t}}$ represents the monthly logarithmic change in the interest rates of three month maturity Turkish T-bill. IPindex $x_{t}$ represents the monthly logarithmic change in Turkish IP index. Gold ${ }_{t}$ is monthly logarithmic change of gold prices. Oil $1_{t}$ is monthly logarithmic change of Brent oil prices. Inflation ${ }_{t}$ represents the monthly logarithmic change in the Turkish inflation rates. Bankrupt $t_{t}$ is monthly logarithmic change in numbers of bankrupt firms and $r_{t-1}$ represents the return of the related stock market index in month $t-1 . r_{t-1}$ is included in the model, in order to get rid of the possible autocorrelation problem.

\begin{tabular}{|c|c|c|c|c|c|c|}
\hline \multirow{2}{*}{$\begin{array}{r}\text { Dep. Var. } \\
\text { Method }\end{array}$} & \multicolumn{2}{|c|}{ National-100 } & \multicolumn{2}{|c|}{ All-Shares } & \multicolumn{2}{|c|}{ Second National } \\
\hline & OLS & ROBUST $^{\mathbf{e}}$ & OLS $^{\bar{d}}$ & ROBUST $^{\mathbf{e}}$ & $\mathbf{O L S}^{\mathbf{d}}$ & ROBUST $^{\mathrm{e}}$ \\
\hline \multirow[t]{2}{*}{ SUICIDE } & $0.15161^{\mathrm{a}}$ & $0.23189^{\mathrm{a}}$ & $0.14539^{a}$ & $0.22646^{\mathrm{a}}$ & 0.03772 & 0.05502 \\
\hline & {$[0.016]$} & $(0.045)$ & {$[0.046]$} & $(0.044)$ & {$[0.067]$} & $(0.054)$ \\
\hline Month Dummies ${ }^{f}$ & $\mathrm{X}$ & $\mathrm{X}$ & $\mathrm{X}$ & $\mathrm{X}$ & $\mathrm{X}$ & $\mathrm{X}$ \\
\hline \multirow[t]{2}{*}{ RAMADAN } & 0.04976 & 0.01963 & 0.04750 & 0.01777 & -0.02284 & -0.00057 \\
\hline & {$[0.030]$} & $(0.028)$ & [0.029] & $(0.027)$ & [0.034] & $(0.033)$ \\
\hline \multirow[t]{2}{*}{$r_{t-1}$} & $-0.11385^{c}$ & $-0.15099^{b}$ & $-0.10902^{c}$ & $-0.14373^{c}$ & 0.04769 & 0.07927 \\
\hline & {$[0.063]$} & $(0.076)$ & {$[0.064]$} & $(0.077)$ & {$[0.080]$} & $(0.070)$ \\
\hline \multirow[t]{2}{*}{ T-BILL } & $-0.19874^{a}$ & $-0.15707^{\mathbf{b}}$ & $-0.19418^{a}$ & $-0.14915^{b}$ & $-0.25892^{\mathrm{a}}$ & $-0.25732^{\mathrm{a}}$ \\
\hline & {$[0.073]$} & $(0.069)$ & {$[0.072]$} & $(0.067)$ & {$[0.068]$} & $(0.082)$ \\
\hline \multirow[t]{2}{*}{ IPINDEX } & 0.04766 & 0.02294 & 0.04593 & 0.01530 & -0.01266 & -0.05831 \\
\hline & {$[0.160]$} & $(0.149)$ & {$[0.153]$} & $(0.146)$ & [0.115] & (0.179) \\
\hline \multirow[t]{2}{*}{ GOLD } & $-0.30525^{c}$ & -0.02361 & $-0.29687^{\mathrm{c}}$ & -0.02556 & -0.08224 & -0.10776 \\
\hline & [0.184] & $(0.196)$ & [0.178] & $(0.191)$ & [0.228] & $(0.236)$ \\
\hline \multirow[t]{2}{*}{ OIL } & 0.05535 & 0.02829 & 0.05364 & 0.03553 & -0.07068 & -0.00216 \\
\hline & {$[0.140]$} & $(0.095)$ & [0.136] & $(0.092)$ & [0.124] & $(0.115)$ \\
\hline \multirow[t]{2}{*}{ INFLATION } & -0.00105 & -0.00243 & -0.00007 & -0.00164 & 0.01544 & 0.01517 \\
\hline & [0.007] & $(0.015)$ & [0.007] & $(0.015)$ & [0.009] & $(0.018)$ \\
\hline \multirow[t]{2}{*}{ BANKRUPT } & -0.05297 & $-0.09775^{b}$ & -0.04921 & $-0.09236^{b}$ & -0.00547 & 0.00574 \\
\hline & [0.047] & $(0.040)$ & [0.045] & $(0.039)$ & [0.043] & $(0.048)$ \\
\hline \multirow[t]{2}{*}{$\alpha$} & $-0.72213^{a}$ & $-1.10970^{\mathrm{a}}$ & $-0.69259^{a}$ & $-1.08375^{a}$ & -0.13620 & -0.22619 \\
\hline & {$[0.236]$} & $(0.238)$ & {$[0.230]$} & $(0.232)$ & {$[0.351]$} & $(0.285)$ \\
\hline Observations & 158 & 160 & 158 & 160 & 156 & 160 \\
\hline Adj. R-sq. & 0.13979 & 0.44192 & 0.13555 & 0.44090 & 0.00180 & 0.19944 \\
\hline F-statistic & $2.27564^{\mathrm{a}}$ & & $2.23086^{\mathrm{a}}$ & & 1.01400 & \\
\hline
\end{tabular}

Table 3: The Results of the Regression Analysis (Model 2).

Note: $\left({ }^{a}\right),\left({ }^{b}\right)$ and $\left({ }^{c}\right)$ have been used to indicate that the coefficient estimations are statistically significant at $1 \%, 5 \%$ and $10 \%$ level, 
respectively. $\left({ }^{d}\right)$ The values given in brackets under related coefficient estimations are Newey-West robust standard errors. $\left({ }^{(}\right)$The values given in parenthesis under related coefficients are robust standard errors. $\left(^{f}\right)$ To narrow the research to a smaller area, the test results related to the months of the year are not reported here.

According to OLS regression results (Table 3), stock prices react negatively to the changes in the T-bill rates, gold prices and its one-day lagged returns. The coefficients related to variables are negative and statistically significant just for National-100 and All-Shares indexes. The findings show that an increase of 1\%, for example, in T-bill rates in month $\mathrm{t}$ is estimated to lower the stock prices by approximately $0.19 \%$ in the same month, all else equal. Similarly, the results stress that an increase of $1 \%$ in gold prices will lower the stock prices by nearly $0.30 \%$. According to robust regression analysis results (as shown in Table 3), the stock prices in National-100 and All-Shares indexes respond negatively to firm bankruptcies, not to gold prices. A standard deviation increase (approximately $66 \%$ ) in the average number of bankrupt firms in month t leads to a decrease of nearly $6 \%$ in stock returns, all else equal. Finally, one day lagged returns of National-100 and All-Shares indexes have negative and statically significant coefficients.

Despite the additions to model (1), the result for coefficient $\beta_{1}$ is still positive and statistically significant for two indexes. This reveals that it is not possible to explain the relationship between suicides and stock returns with the reaction given to economic indicators by investor.

\subsection{The Model Where Alternative Mood Proxies Are Controlled}

A mentioned before, a good number of researchers analyzed the response of stock prices (or investors) to exogenous factors (e.g. weather, temperature) which affects the investor mood. Furthermore, a significant number of research findings tried to show the correlation between the exogenous factors and suicides. Majority of the studies have interrelated findings. For example seasonal affective disorder (SAD) or weather decreases the prices of stocks (Kamstra et al., 2003; Saunders, 1993). Similarly, seasons or weather may be the cause of suicides (Makris, 2013; Salib, 1997). At this point some people may wonder if the positive correlation between stock prices and suicides will vanish if the other exogenous factors that affect mood are considered. To get rid of this curiosity, alternative mood proxies are controlled. Thus the model (2) is revised as shown below:

$$
\begin{aligned}
r_{t}= & \alpha+\beta_{1} \ln \left(\text { Suicide }_{t}\right)+\sum_{n=1}^{6} \gamma_{n} D M_{n t}+\delta_{l} D_{1} R_{t}+\lambda_{1} r_{t-1} \\
& +\lambda_{2} \text { TBill }_{\mathrm{t}}+\lambda_{3} \text { IPindex }_{\mathrm{t}}+\lambda_{4} \text { Gold }_{\mathrm{t}}+\lambda_{5} \text { Oil }_{\mathrm{t}}+\lambda_{6} \text { Inflation }_{\mathrm{t}}+\lambda_{7} \text { Bankrupt }_{\mathrm{t}} \\
& +\varphi_{1} \text { Temp }_{\mathrm{t}}+\varphi_{2} \text { DFall }_{\mathrm{t}}+\varphi_{3} \text { SAD }_{\mathrm{t}}+\varphi_{4} \text { Cloud }_{\mathrm{t}}+\varphi_{5} \text { Rain }_{\mathrm{t}}+\varphi_{6} \text { Wind }_{\mathrm{t}}+\varepsilon_{t}
\end{aligned}
$$

Temp $\mathrm{t}_{\mathrm{t}}$ represents the monthly logarithmic change in Istanbul's mean temperature; Cloud $\mathrm{t}_{\mathrm{t}}$ the monthly change in mean cloudiness of Istanbul; Rain ${ }_{t}$ represents the monthly logarithmic change in the rain amount (mm) in Istanbul and Wind $\mathrm{t}_{\mathrm{t}}$ is the monthly logarithmic change in the speed of wind $(\mathrm{m} / \mathrm{sec})$ in Istanbul. Fall $\mathrm{t}_{\mathrm{t}}$ and $\mathrm{SAD}_{\mathrm{t}}$ variables are included in the model (3) to control the seasonal affective disorder as Kamstra et al. (2003) did. Fall $\mathrm{t}_{\mathrm{t}}$ is the dummy variable that takes the value of 1 in fall and 0 otherwise and $\mathrm{SAD}_{\mathrm{t}}$ is the standardized value of mean night time in Istanbul in $\mathrm{t}-$ month ${ }^{16} . \mathrm{DM}_{\mathrm{nt}}$ is the dummy variables for the six months of the year (except fall and winter months ${ }^{17}$ ) because there is multicollinearity between fall and winter months and SAD and FALL variables included in the study. Table 4 shows the results of the regression model (3).

The sign and bigness of coefficient $\beta_{1}$ overlap the results of model (1) and (2). When everything is steady, it is supposed that an increase of $20 \%$ in the suicides compared to prior period will bring an increase of nearly $2.8 \%$ in the National-100 index (3.8\%, according to robust regression).

The results of both OLS and Robust regression analysis (Table 4) show that the coefficients of FALL and CLOUD variables are positive and statistically significant for both indexes (National-100 and All-Shares). The fall season is estimated to increase the stock prices of the related indexes nearly 5 basis points ( 6 basis points, according to robust regression), all else equal. Similarly, a standard deviation increase (nearly 34\%) in Istanbul's average cloudiness will raise the stock prices nearly $1.8 \%$, all else equal.

People cherish their lives on sunny days more than they do on cloudy or rainy days (Schwarz and Clore, 1983) so the fall and cloudy weather are the representatives of negative mood. Some studies showed evidence of cloudy day (i.e. negative mood) caused fall in stock returns (Saunder, 1993; Hirshleifer and Shumway, 2003). However, the related results of the model (3) differ from the former results in the literature interestingly but they contribute to the robustness

\footnotetext{
${ }^{16} \mathrm{SAD}$ is calculated as Kamstra et al. (2003) did.

$\mathrm{SAD}_{\mathrm{t}}= \begin{cases}\mathrm{H}_{\mathrm{t}}-12 & \text { for months in the fall and winter } \\ 0 & \text { otherwise }\end{cases}$
}

Here, $\mathrm{H}_{\mathrm{t}}=$ the time period between sunset and sunrise.

${ }_{17}$ There is season fall between September 23 and December 21 in the northern hemisphere. Since monthly data are used in this study, October, November and December are supposed to be fall months in this study. Similarly, January, February and March are supposed to be winter months. 
of the positive correlation between suicides and stock returns in the Istanbul Stock Market. In this way, cloudiness, which is thought to affect mood negatively boosts the stock prices in the Turkish stock exchange, as suicides. More interestingly, according to robust regression (Table 4) the stock prices in the Turkish stock market positively respond to the speed of the wind which is another negative mood proxy (contrary to the study of Keef and Roush, 2005). The findings related to coefficients of alternative mood proxy variables are fairly interesting and also present strong evidence of the positive correlation between suicides and stock returns.

As a result, the positive correlation still goes on after well-known anomalies such as rain, cloudiness, SAD, temperature and wind are kept under control.

Table 4: The Results of the Regression Analysis (Model 3).

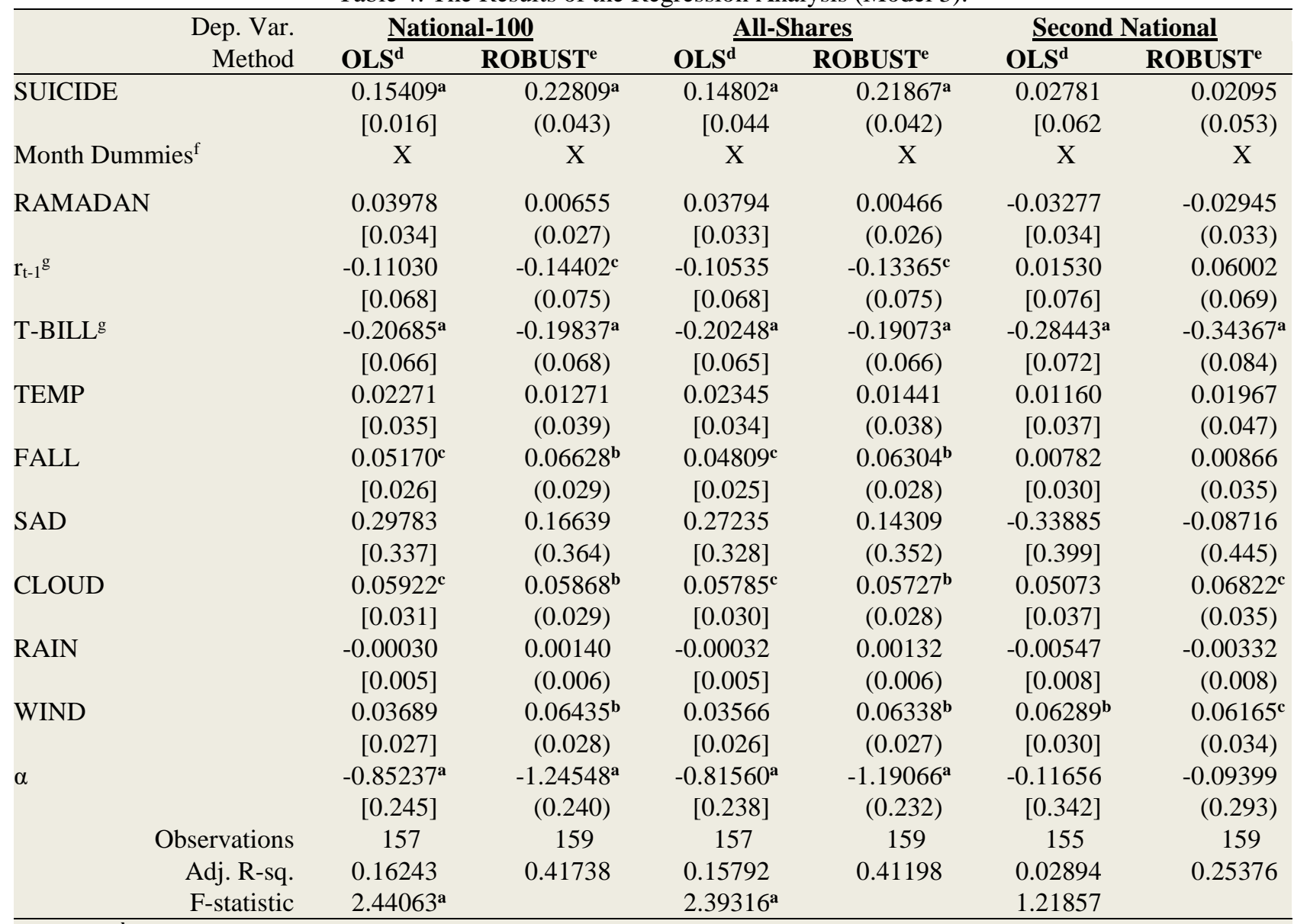

Note: $\left({ }^{\mathbf{a}}\right),\left({ }^{\mathbf{b}}\right)$ and $\left({ }^{c}\right)$ have been used to indicate that the coefficient estimations are statistically significant at $1 \%, 5 \%$ and $10 \%$ level, respectively. $\left({ }^{d}\right)$ The values given in brackets under related coefficient estimations are Newey-West robust standard errors. $\left({ }^{\mathbf{e}}\right)$ The values given in parenthesis under related coefficients are robust standard errors. $\left(^{f}\right)$ In order to save space, the test results related to the months of the year are not reported here. $(\mathbf{g})$ In order to save space, only the statistically significant macroeconomic variables are included here.

\subsection{The Use of Alternative Suicide Measure (Discrete Variable)}

Some studies in the behavioural finance literature employed mood proxies such as daylight (Hirshleifer and Shumway, 2003) and air temperature (Cao and Wei, 2005) as continuous variables and some studies employed mood proxies such as football match results (Berument and Ceylan, 2012) as discrete variables. I employ suicides representing negative mood as continuous variables in the model (1), (2) and (3). In the model (4), which is formed to ensure the robustness of analysis results, suicide cases are included in the analysis as discrete variable.

$$
\begin{aligned}
r_{t}= & \alpha+\beta_{1} \text { DSuicide }_{t}+\sum_{n=1}^{6} \gamma_{n} \text { DM }_{n t}+\delta_{1} \text { DMR }_{t}+\lambda_{1} r_{t-1} \\
& +\lambda_{2} \text { TBill }_{\mathrm{t}}+\lambda_{3} \text { IPindex }_{\mathrm{t}}+\lambda_{4} \text { Gold }_{\mathrm{t}}+\lambda_{5} \text { Oil }_{\mathrm{t}}+\lambda_{6} \text { Inflation }_{\mathrm{t}}+\lambda_{7} \text { Bankrupt }_{\mathrm{t}} \\
& +\varphi_{1} \text { Temp }_{\mathrm{t}}+\varphi_{2} \text { DFall }_{\mathrm{t}}+\varphi_{3} \text { SAD }_{\mathrm{t}}+\varphi_{4} \text { Cloud }_{\mathrm{t}}+\varphi_{5} \text { Rain }_{\mathrm{t}}+\varphi_{6} \text { Wind }_{\mathrm{t}}+\varepsilon_{t}
\end{aligned}
$$


Where, DSuicide $\mathrm{t}_{\mathrm{t}}$ is the dummy variable which takes a value of 1 if the number of suicide cases exceeds $228^{18}$ in month $\mathrm{t}$ and 0 otherwise. The findings ${ }^{19}$ demonstrate that the coefficient $\beta_{1}$ of the suicide dummy variable is statistically significance at $1 \%$ level and still positive for two indexes. The stock returns in the months suicides exceeds average level, are estimated to be 6 basis points more than that in the other months. This is totally consistent with the analyses of the model (1), (2) and (3). The regression coefficient estimate results of other variable are similar to the model (1), (2) and (3), as well.

This paper, depending on the entire regression analyses made so far claim that, there is a positive correlation between the suicides and the returns of stocks traded on BIST. This correlation leads to the acceptance of the hypothesis $\left(\mathrm{H}_{1 b}\right)$ of this study ${ }^{20}$. This means that in times of negative mood the risk perception decreases and the investors increase their demands for risky assets.

\section{Concluding Remarks}

This paper aims to analyze the effect of the suicide cases in Turkey on the stock buying and selling decisions of investors trading on Bourse Istanbul (in other words, the effect of the suicides on the stock returns). I employ suicide cases caused by negative mood as a proxy variable to represent negative mood, instead of events or situations thought to cause the negative mood. The suicide case is a novel mood proxy used to investigate the response of stock markets to variations in investor mood. The findings of the study reveal that the demands for stocks and eventually stock prices (returns) increase in periods of increases in suicide cases when negative mood dominates over the society.

The related findings in this paper can be evaluated in periods of negative mood domination in the Turkish stock market, "mood repair" instinct (Isen and Geva, 1987) dominates. This instinct prompts depressed investors who are in a negative mood to invest in risky assets to reward themselves because they want to repair their negative mood by this way (Andrade, 2005; Tice, Bratslavsky and Baumeister, 2001). The results are in agreement with a relatively few studies in the literature. Some former studies point out that people in negative mood tend to prefer risky choices (with high earner) to make themselves happy (Isen and Geva, 1987; Leith and Baumeister, 1996). Although Raghunathan and Pham (1999) found that anxious people abstain from risk, they also point out that sad people tend to reward themselves by taking high risk. Bruyneel et al. (2009) also stress that people in negative mood are led to risky assets. Such results can be met in studies of Lin, Yen and Chuang (2007) and Leith and Baumeister (1996). Lin, Yen and Chuang (2007) showed some evidence that people who feel fine at the time of decision making, abstain from risk. However, people who feel sad are more eager to take risks and prefer choices that are more likely to bring gain. Similarly, Leith and Baumeister (1996) also observed that people in negative mood prefer higher risk and more profitable choices (it was lottery, in their study) to low risk and less profitable choices. Thaler and Johnson (1990) express that people who experienced prior losses (people in negative mood) find risky choices more attractive for the purpose of recovering the losses (break-even effects).

The findings obtained from the Turkish stock market can be an outcome of the negative mood which prompts individuals to buy (not just the risky assets, but all assets). Former studies have shown that mood plays a significant role in consumer behaviours (Gardner and Vandersteel, 1984; Westbrook, 1980). As some studies suggest, negative mood raises the will to buy and consume. For example, the negative mood that dominated the society after September 11 terrorist attack increased the consumption expenditures extremely in the following quarter (Sergeant, 2011). Moreover, Lejoyeux and Weinstein (2010) prove that the individuals with excessive shopping behavior have psychological disorders and their buying tendency diminishes as their negative mood repairs. Finally, Lejoyeux et al. (1996) found that the increases in the buying behaviors of individuals cure them as if they receive an antidepressant treatment in times of negative mood domination. Therefore, the findings obtained from this paper can be a result of the increase in demands for all assets (not just the risky assets) during periods of negative mood.

This paper results which show the effect of social psychology on the stocks traded at BIST reveal that agents in the BIST keep a close watch on the psychological state of society. According to active portfolio strategy, agents at the stock exchanges make an investment decision by analyzing all of the factors influencing the stock prices. As a result of this paper, social psychology is a driver significantly affecting the stock prices. For this reason, agents may have an opportunity to earn abnormal return by monitoring the factors believed to have an effect on social psychology (here, suicide, full moon, weather etc.)

Potential researchers should analyze the suicide-return relationship at different stock markets and time periods. Potential researchers can also contribute to the literature, finding an answer to the following question: Is the root cause of the increases in the stock returns the negative mood that prompts individuals to buy just risky assets or all assets?

\footnotetext{
${ }^{18}$ It is the monthly average of suicide cases in Turkey between 2000 and 2013.

${ }^{19}$ In order to space limitation, the regression analysis results related to the model (4) are not given here.

${ }^{20} \mathrm{In}$ fact, the related hypothesis has not been accepted for the second-national-market but since All-Shares index has the power to represent both the national and the second-national market, the related hypothesis has been supposed to be accepted by the whole of the Turkish stock market.
} 


\section{REFERENCES}

Al-Rjoub, S. A. (2005). The adjustments of stock prices to information about inflation: evidence from MENA countries. Applied Economics Letters 12(14), 871-879

Andrade, E. B. (2005). Behavioral consequences of affect: Combining evaluative and regulatory mechanisms. Journal of Consumer Research 32, 355-362.

Arkes, H. R., Herren, L. T. and Isen, A. M. (1988). The role of potential loss in the influence of affect on risk-taking behavior. Organizational behavior and human decision processes 42(2), 181-193.

Atasoy, E. and Ertürk, M. (2014). Geography of Suicide: Russia Example. Eastern Geographical Review 19(31), $37-64$.

Bakian, A. V., Huber, R. S., Coon, H., Gray, D., Wilson, P., McMahon, W. M. and Renshaw, P. F. (2015). Acute air pollution exposure and risk of suicide completion. American journal of epidemiology 181(5), 295-303.

Barry, E. S., Naus, M. J. and Rehm, L. P. (2006). Depression, implicit memory, and self: A revised memory model of emotion. Clinical Psychology Review 26(6), 719-745.

Batıgün, A. D. (2008). İntihar olasılı̆̆ı ve cinsiyet: İletişim becerileri, yaşamı sürdürme nedenleri, yalnızlık ve umutsuzluk açısından bir inceleme. Türk Psikoloji Dergisi 23(62), 65-75.

Berument, M. H. and Ceylan, N. B. (2012). Effects of soccer on stock markets: The return-volatility relationship. The Social Science Journal 49(3), 368-374.

Białkowski, J., Etebari, A. and Wisniewski, T. P. (2012). Fast profits: Investor sentiment and stock returns during Ramadan. Journal of Banking and Finance 36(3), 835-845.

Bower, G. H. (1981). Mood and memory. American psychologist 36(2), 129-148.

Bozkurt, İ. (2015). Investigation of the Effects of the Moon on Stock Returns: An Empirical Application on ISE. Iktisat Işletme ve Finans 30(352), 55-78.

Bozkurt, İ. (2014). Testing the Presence of Contagion and Competitive Effect on Sport Club's Stock Returns around Soccer Match Results: Evidence from Turkey. Finans Politik ve Ekonomik Yorumlar 51(591), 37-52.

Bruyneel, S., Dewitte, S., Franses, P. H. and Dekimpe, M. G. (2009). I felt low and my purse feels light: Depleting mood regulation attempts affect risk decision making. Journal of Behavioral Decision Making 22, 153-170.

Campbell, J. Y., Hilscher, J. and Szilagyi, J. (2008). In Search of Distress Risk. The Journal of Finance 63 (6), 2899 2939

Cao, M. and Wei, J. (2005). Stock market returns: A note on temperature anomaly. Journal of Banking and Finance 29(6), 1559-1573.

Chang, E. C. and Pinegar, J. M. (1989). Seasonal fluctuations in industrial production and stock market seasonals. Journal of Financial and Quantitative Analysis 24(01), 59-74.

Chen, Y. Y., Chen, F. and Yip, P. S. (2011). The impact of media reporting of suicide on actual suicides in Taiwan, 2002-05. Journal of epidemiology and community health 65(10), 934-940.

Conte, A., Levati, M. V. and Nardi, C. (2013). The role of emotions on risk preferences: An experimental analysis (No. 2013-046). Jena Economic Research Papers.

Dichev, I. D. (1998). Is the risk of bankruptcy a systematic risk?. The Journal of Finance 53 (3), 1131-1147.

Dowling, M. and Lucey, B. M. (2005). Weather, biorhythms, beliefs and stock returns-some preliminary Irish evidence. International Review of Financial Analysis 14(3), 337-355.

Eskin, M., Kaynak-Demir, H. and Demir, S. (2005). Same-sex sexual orientation, childhood sexual abuse, and suicidal behavior in university students in Turkey. Archives of sexual behavior 34(2), 185-195.

Encrenaz, G., Contrand, B., Leffondré, K., Queinec, R., Aouba, A., Jougla, E., Miras, A. and Lagarde, E. (2012). Impact of the 1998 football world cup on suicide rates in France: Results from the national death registry. Suicide and Life-Threatening Behavior 42(2), 129-135.

Gardner, M. P. and Vandersteel, M. (1984). The consumer's mood: an important situational variable. Advances in consumer research 11(1), 525-529.

Griffin, J. M. and Lemmon, M. L. (2002). Book-to-market equity, distress risk, and stock returns. The Journal of Finance 57 (5), 2317-2336.

Henriksson, M. M., Aro, H. M., Kuoppasalmi, K. I. and Jouko, K. L. (1993). Mental disorders and comorbidity in suicide. Am J Psychiatry 1(50), 935-940.

Herve, D. B. G. H., Chanmalai, B. and Shen, Y. (2011). The study of causal relationship between stock market indices and macroeconomic variables in Cote d'Ivoire: Evidence from error-correction models and Granger causality test. International Journal of Business and Management 6(12), 146-169.

Hirshleifer, D. and Shumway, T. (2003). Good day sunshine: Stock returns and the weather. The Journal of Finance 58(3), 1009-1032.

Hockey, G. R. J., John Maule, A., Clough, P. J. and Bdzola, L. (2000). Effects of negative mood states on risk in everyday decision making. Cognition and Emotion 14(6), 823-855.

Huber, P. J. (1981). Robust Statistics. New York: John Wiley and Sons,Inc. 
Ibrahim, M. H. and Yusoff, S. W. (2001). Macroeconomic variables, exchange rate and stock price: A Malaysian perspective. International Journal of Economics, Management and Accounting $9(2$.

Iglewicz, B. and Hoaglin, D. (1993). How to detect and handle outliers. Milwaukee, WI.: ASQC Quality Press.

Isen, A. M. and Geva, N. (1987). The influence of positive affect on acceptable level of risk: The person with a large canoe has a large worry. Organizational Behavior and Human Decision Processes 39(2), 145-154.

Isen, A. M. and Patrick, R. (1983). The effect of positive feelings on risk taking: When the chips are down. Organizational behavior and human performance 31(2), 194-202.

Isen, A. M., Shalker, T. E., Clark, M. and Karp, L. (1978). Affect, accessibility of material in memory, and behavior: A cognitive loop?. Journal of personality and social psychology 36(1), 1-12.

Johnson, E. J. and Tversky, A. (1983). Affect, generalization, and the perception of risk. Journal of personality and social psychology 45(1), 20-31.

Kamstra, M. J., Kramer, L. A. and Levi, M. D. (2003). Winter blues: A SAD stock market cycle. American Economic Review, 324-343.

Kaplan H. I. and Sadock B. J. (2004). Klinik psikiyatri. In Abay, E. (Ed.), Intihar. 361-366. İstanbul: Nobel T1p Kitabevi.

Kavanagh, D. J. and Bower, G. H. (1985). Mood and self-efficacy: Impact of joy and sadness on perceived capabilities. Cognitive Therapy and Research 9(5), 507-525.

Keef, S. P. and Roush, M. L. (2005). Influence of weather on New Zealand financial securities. Accounting and Finance 45, 415-437.

Kuwornu, J. K. and Owusu-Nantwi, V. (2011). Macroeconomic variables and stock market returns: full information maximum likelihood estimation. Research Journal of Finance and Accounting 2(4), 49-63.

Kütük, Y. (2011). Türkiye'de İntiharların Ekonomik ve Sosyal Göstergelerle İlişkisi. Yayınlanmamış Yükssek Lisans Tezi. İstanbul Teknik Üniversitesi, İstanbul.

Large, M., Sharma, S., Cannon, E., Ryan, C. and Nielssen, O. (2011). Risk factors for suicide within a year of discharge from psychiatric hospital: a systematic meta-analysis. Australian and New Zealand Journal of Psychiatry 45(8), 619-628.

Leith, K. P. and Baumeister, R. F. (1996). Why do bad moods increase self-defeating behavior? Emotion, risk taking and self-regulation. Journal of Personality and Social Psychology 71, 1250-1267.

Lejoyeux, M. and Weinstein, A. (2010). Compulsive Buying. The American Journal of Drug and Alcohol Abuse 36, 248-253. DOI: 10.3109/00952990.2010.493590

Lejoyeux, M., Ades, J., Tassain, V. and Solomon, J. (1996). Phenomenology and Psychopathology of uncontrolled buying. Am J Psychiatry 153(12), 1524-1529.

Lepori, G. M. (2010). Positive mood, risk attitudes, and investment decisions: Field evidence from comedy movie attendance in the US. Available at SSRN: $\underline{\text { htp: }: / \text { ssrn.com/abstract }=1690476}$ or http://dx.doi.org/10.2139/ssrn.1690476

Lepori, G.M. (2015). Investor mood and demand for stocks: Evidence from popular TV series finales. Journal of Economic Psychology 48(2015), 33-47.

Levy, T. and Yagil, J. (2011). Air pollution and stock returns in the US. Journal of Economic Psychology 32(3), 374383.

Lin, C. H., Yen, H. R. and Chuang, S.-C. (2007). The effects of emotion and need for cognition on consumer choice involving risk. Journal of Business and Psychology 22(1), 65-78.

Loewenstein, G., Weber, E., Hsee, C. and Welch, N. (2001). Risk As Feelings. Psychological Bulletin 127 (2), $267-286$.

Makris, G. D., Reutfors, J., Ösby, U., Isacsson, G., Frangakis, C., Ekbom, A. and Papadopoulos, F. C. (2013). Suicide seasonality and antidepressants: a register-based study in Sweden. Acta Psychiatrica Scandinavica 127(2), 117-125.

Mick, D. G. and DeMoss, M. (1990). Self-gifts: Phenomenological insights from four contexts. Journal of Consumer Research 322-332.

Mittal, V. and Ross, W. T. (1998). The impact of positive and negative affect and issue framing on issue interpretation and risk taking. Organizational Behavior and Human Decision Processes 76(3), 298-324.

Mayer, J. D., Gaschke, Y. N., Braverman, D. L. and Evans, T. W. (1992). Mood-congruent judgment is a general effect. Journal of Personality and Social Psychology 63(1), 119.

Narayan, P. K. and Gupta, R. (2015). Has oil price predicted stock returns for over a century?. Energy Economics 48, 18-23.

Nygren, T. E., Isen, A. M., Taylor, P. J. and Dulin, J. (1996). The influence of positive affect on the decision rule in risk situations: Focus on outcome (and especially avoidance of loss) rather than probability. Organizational Behavior and Human Decision Processes 66(1), 59-72.

Özgüven, H. D., Soykan, Ç., Haran, S. and Gençöz, T. (2003). Importance of Problem Solving Skills, Perceived Social Support, and Depression and Anxiety Symptoms on Suicide Attempts. Türk Psikoloji Dergisi 18(52), 1-11.

Raghunathan, R. and Pham, M. T. (1999). All negative moods are not equal: Motivational influences of anxiety and sadness on decision making. Organizational Behavior and Human Decision Processes 79(1), 56-77. 
Reeves, A., Stuckler, D., McKee, M., Gunnell, D., Chang, S. S. and Basu, S. (2012). Increase in state suicide rates in the USA during economic recession. Lancet 380(9856), 1813-1814.

Rousseeuw, P. J. and Leroy, A. M. (1987). Robust regression and outlier detection. New York: .John Wiley and Sons.

Salib, E. (1997). Elderly suicide and weather conditions: is there a link?. International Journal of Geriatric Psychiatry 12(9), 937-941.

Saunders, E. M. (1993). Stock prices and Wall Street weather. The American Economic Review 1337-1345.

Schwarz, N. and Clore, G. L. (1983). Mood, misattribution, and judgments of well-being: Informative and directive functions of affective states. Journal of personality and social psychology 45(3), 513-523.

Schwarz, N. and Clore, G. L. (1988). How do I feel about it? The informative function of affective states. In K. Fiedler and J. Forgas (Eds.), Affect, cognition, and social behavior (pp.44-62). Göttigen, Federal Republic of Germany: Hogrefe.

Sergeant, K. (2011). Consumer confidence and economic growth: A case study of Trinidad and Tobago. 4th Biennial International Conference on Business, Banking and Finance, Trinidad.

Seyyed, F. J., Abraham, A. and Al-Hajji, M. (2005). Seasonality in stock returns and volatility: The Ramadan effect. Research in International Business and Finance 19(3), 374-383.

Smith, G. (2001). The price of gold and stock price indices for the United States. The World Gold Council 8, 1-16.

Stracca, L. (2004). Behavioral finance and asset prices: Where do we stand?. Journal of Economic Psychology 25(3), 373-405.

Thaler, R. H. and Johnson, E. J. (1990). Gambling with the house money and trying to break even: The effects of prior outcomes on risky choice. Management science 36(6), 643-660.

Tice, D. M., Bratslavsky, E. and Baumeister, R. F. (2001). Emotional distress regulation takes precedence over impulse control: If you feel bad, do it. Journal of Personality and Social Psychology 80, 53-67.

Triantafyllou, K. andAngeletopoulou, C. (2011). Increased suicidality amid economic crisis in Greece. Lancet. Correspondence 378(9801), 1459-1460.

Vance, D. E. (1995). Belief in lunar effects on human behavior. Psychological reports 76(1), 32-34.

Westbrook, R. A. (1980). Intrapersonal affective influences on consumer satisfaction with products. Journal of consumer research, 49-54.

Wright, W. F. andBower, G. H. (1992). Mood effects on subjective probability assessment. Organizational behavior and human decision processes 52(2), 276-291.

Yuen, K. S. and Lee, T. M. (2003). Could mood state affect risk-taking decisions?. Journal of affective disorders 75(1), $11-18$.

Zillmann, D. (1988). Mood management through communication choices. American Behavioral Scientist 31, $327-340$. 